\title{
IMPACT OF UREA-TREATED OLIVE TREES BY-PRODUCTS ON BARKI EWE'S NUTRIENTS DIGESTIBILITY AND MILK PRODUCTIVITY
}

\author{
A.A. Aboamer ${ }^{1}$, Hend A. Aziz ${ }^{2}$, H. H. Azzaz ${ }^{1}$, Hoda Alzahar ${ }^{1}$ and H.A. Murad ${ }^{1}$ \\ 1Dairy Science Department, National Research Centre, 33 Buhouth St, Dokki, Giza, Egypt \\ 2 Animal Nutrition Department, Desert Research Center, Cairo, Egypt. \\ *Corresponding author Tel: 202 33068626; Fax: 202 33370931; E-mail address: \\ hosam19583@gmail.com, P.O.B 12622, Dokki, Cairo, Egypt.
}

(Received 14/11/2018, accepted 26/12/2018)

\section{SUMMARY}

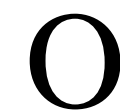

live trees by-products (OTB) has high fiber and low protein content that could limit its use for feeding animals. This work aimed to investigate the effect of replacement of berseem hay in the diet of lactating Barki ewes by OTB treated with increasing levels of urea on Animal's nutrient digestibility, milk yield and milk composition. Thirty-five of lactating Barki ewes after one week of parturition were randomly assigned to five groups (seven each). The first; control group $(\mathrm{CBH})$ was fed concentrate feed mixture (CFM) plus berseem hay. The second group (UOTB) was fed CFM + untreated OTB as a replacement of berseem hay. While, OTB2, OTB4 and OTB6 groups were fed CFM + OTB treated with 2\%, 4\% and 6\% urea (on DM), respectively. Urea treatment significantly improved the crude protein $(\mathrm{CP})$ while decrease fiber fractions content of the treated OTB. Total volatile fatty acids (TVFA's), total protein, NPN and ammonia N levels in the rumen were increased $(\mathrm{p}<0.05)$ in all groups fed OTB treated with urea. Daily milk yield, fat corrected milk (FCM) and composition were slightly increased in groups fed treated OTB compared to both untreated OTB and control group. Ewes fed OTB treated with $4 \%$ urea had the highest values $(p<0.05)$ for milk production and it's composition. Feeding olive trees by-products treated with $4 \%$ urea as a replacement of berseem hay significantly improved nutrients digestibility and milk production performance of Barki ewes.

Keywords: Barki ewes, Urea, Olive trees by-products, Nutrients digestibility and Milk production.

\section{INTRODUCTION}

Mediterranean countries produce more than $76 \%$ of the global production of olive oil (International olive council, 2006). In 2011, Egypt exported 11\% of the world's table olive (International olive council, 2006) that left huge amounts of olive trees by products. One olive tree could produce annually about $25 \mathrm{~kg}$ of leaves and branches (olive trees by-products OTB) (Delgado-Pertíñez et. al., 1998). These residues could be useful for feeding small ruminant during the lack of availability of forages (Molina-Alcaide and Yáñez-Ruiz, 2008). Actually, OTB may play an important role in the integrated use of the available resources and reducing the environmental impact (Molina-Alcaide and Nefzaoui, 1996; Azzaz et. al., 2018).

The nutritive value of olive trees by-products varies depending on the methods and duration of the preservation. Fresh OTB has greater nutritional values and drying may preserve it, but excess drying could decrease their intake and nutritive value (Delgado-Pertínez et. al., 1998). Also, ensiling could be used as a necessary process for keeping OTB for use over the whole year, as these residues seasonally produced.

The chemical composition and nutritional values of the OTB had been studied in several works (MolinaAlcaide and Nefzaoui, 1996; Yáñez Ruiz et al., 2004). Its chemical composition varies according to many factors such as its origin, proportion of branches, preservation and storage conditions, climatic conditions, and degree of contamination with soil (Azzaz et. al., 2018). Olive trees by-products (OTB) is considered as a rich fibrous source (33-56 \% NDF/ kg DM) with high content of lignin (16-21\% ADL/kg DM) limiting the degradability of cell wall and crude protein (CP) contents (Molina-Alcaide and Nefzaoui, 1996). Its CP content is low (70-129 g/kg DM) with low digestibility (Delgado-Pertínez et. al., 1998; Molina-Alcaide and 


\section{Aboamer et al.}

Yáñez-Ruiz, 2008) due to its high contents of acid detergent insoluble nitrogen (ADIN). However, the high dry matter (DM) content and the lack of fermentable sugars should be considered (Molina-Alcaide and Yáñez-Ruiz, 2008). Both organic matter (OM) and CP digestibility of OTB is low and variable. In this concern, treatment with urea could improve the OM digestibility by 19\% (Molina Alcaide et al., 2003).

In the previous work (Romaniello et al., 2018), treatment of OTB with urea resulted in significant increase in nutrient digestibility, nutritive values and the growth performance of ewe lambs. The optimal level for treatment with urea and the effect on milk production still not discussed.

Therefore, this work aimed to: 1) consider the effect of chemical treatment with increasing levels of urea on fiber and protein content of OTB. 2) Study effects of feeding treated OTB as an alternative for berseem hay on feed intake, nutrients digestibility, some rumen and blood parameters, and milk production by lactating Barki ewes.

\section{MATERIALS AND METHODS}

Olive trees by products (OTB) were collected from olive farms along Cairo - Alexandria Saharan Road, then chopped and dried naturally for two weeks and packed till use. Feeding and lactation experiments were conducted at a private farm (Alsttar farm for animal production), Khatatba city, Monofia governorate, Egypt. The entire experimental period was extended from January 20, 2018 to April 20, 2018. This experimental research has been conducted according to the experimental and ethical rules of the National Research Centre of Egypt.

Treatments of olive tree's by-products with urea: The collected OTB was chopped to $2-3 \mathrm{~cm}$ before air drying for 15 day to reach 10-15\% moisture until used. The air-dried OTB was then moistened for $40 \%$ before sprayed with different levels of urea solution $(1,2,3,4,5$, and $6 \%$ on DM basis). After that, $10 \%$ of molasses solution on DM base was added as energy source in ensiled mixture. Finally, the mixtures were kept in tightly closed plastic bag for 21 days until opened and oven dried at $70^{\circ} \mathrm{C}$ for further chemical analysis by standard methods (AOAC, 1997). These were AOAC index no. 942.05 for DM and total ash, AOAC 977.02 for CP and AOAC 963.15 (petroleum ether extraction) for EE. Neutral detergent fiber (NDF), acid detergent fiber (ADF) and acid detergent lignin (ADL) were determined (Van Soest et. al., 1991).

Animals and feeding: Thirty-five of lactating Barki ewes after one week of parturition were randomly assigned to five groups (seven in each) using complete random design. Ewes have been allowed to feed on dry matter up to $5 \%$ of their body weight. The first group (CBH) was fed on concentrate feed mixture (CFM: $60 \%$ corn, $22 \%$ soybean meal , $15 \%$ wheat bran, $1 \%$ limestone, $1 \%$ minerals and vitamins mixture and $1 \%$ $\mathrm{NaCl}$ ) at $70 \%$ of allowance and berseem hay was offered ad lib. The second group (UOTB) was fed on untreated olive trees by-product as a replacer for berseem hay. However, groups (OTB2, OTB4, and OTB6) were fed treated OTB with 2, 4 and 6\% urea (on DM), respectively. Diet offered twice per day in two equal portions at 7 a.m. and 4 p.m. The offered and the refusals were weighted daily and the animals were weighted every month.

Digestibility trials: At the last week of each month of the experimental period, fecal grab samples were collected from four animals (each group) in cloth bag connected to the animal back, for five successive days from each animal. A representative samples (10\% from the collected feces) were dried in an oven at $70 \mathrm{C}$ for $24 \mathrm{hrs}$. The dried feces from each animal were mixed and ground to pass a $1 \mathrm{~mm}$ sieve in a feed mill (FZ102, Shanghai Hong Ji instrument Co., Ltd., Shanghai, China) for their approximate analysis by standard methods (AOAC, 1997).Acid insoluble ash was used as an internal marker for determination of nutrients digestion coefficients. The digestibility coefficient of nutrient was calculated according to the following formula (Ferret et. al., 1999):

$$
\text { Digestion co-efficient }=\quad 100-\left[100 x \frac{\% \text { indicator in feed }}{\% \text { indicator in feces }} \times \frac{\% \text { nutrient in feces }}{\% \text { nutrient in feed }}\right]
$$

Rumen parameters: At the end of the digestibility trials, $100 \mathrm{ml}$ of rumen fluid was obtained using stomach tube at 4 hours after morning feeding for three successive days. The ruminal fluid was strained through three layers of cheese cloth, $\mathrm{pH}$ was immediately measured, then $1 \mathrm{ml}$ toluene and $1 \mathrm{ml}$ paraffin oil 
were added and stored in deep freeze at $\left(-20^{\circ} \mathrm{C}\right)$ until analysis. Ammonia nitrogen, total nitrogen and nonprotein nitrogen (NPN) concentration were determined according to A.O.A.C standard procedure (AOAC, 1997). The true protein nitrogen was calculated by subtracting the non-protein nitrogen content from total nitrogen content. Total volatile fatty acids (TVFAs) was determined (Dijkstra, 1994).For ruminal protozoal counting and classification, the ruminal fluid was strained through one layer of cheese cloth, then 2 drops of formalin were immediately add to the strained ruminal fluid (Naga et. al., 1969).

Blood parameters: samples were collected in glass tubes from jugular vein of each animal at $4 \mathrm{~h}$ after morning feeding for the last 3 days of each month of the experimental period. Serum was separated by centrifugation at $4000 \mathrm{x} \mathrm{g} / 20 \mathrm{~min}$. after coagulate at room temperature and kept frozen at $-20^{\circ} \mathrm{C}$ for later analysis. Serum total protein, albumin, urea, aspartate aminotransferase (AST) and alanin aminotransferase (ALT) was determined using commercial kits (Stanbio Laboratory, Boerne, TX, USA) following manufacturer instructions. Globulin was calculated by subtracting the albumin from total protein.

Milk yield and composition: Ewes were milked twice a day for three successive days at the end of each month of the experimental period, at 8.00 a.m. and 4.00 p.m. Then, milk yield from the morning and evening milking were mixed together, recorded and a representative sample were kept at $-20^{\circ} \mathrm{C}$ for later analysis for total solids, fat, protein and lactose by Bentley150 infrared milk analyzer (Bentley Instruments, Chaska, MN, USA). Solids-not-fat (SNF) was calculated by subtracting fat from total solids percentage. Fat corrected milk (4\% fat) was calculated by using the following equation (Azzaz et. al., 2015):

$\mathrm{FCM}=0.4 \mathrm{M}+15 \mathrm{~F}, \quad$ Where: $\mathrm{M}=$ milk yield $(\mathrm{g})$ and $\mathrm{F}=$ fat yield $(\mathrm{g})$.

Statistical analysis: The obtained data were statistically analyzed for one-way ANOVA using SAS software (SAS, 1998). The experimental model was:

$$
Y_{i j}=M+T_{i}+e_{i j},
$$

Where: $\mathrm{Y}_{i j}=$ experimental observation; $\mathrm{M}=$ general mean; $\mathrm{T}_{i}=$ effect of treatment; $\mathrm{e}_{i j}=$ experimental error; Duncans multiple tests were applied for comparison of means (Duncan, 1955).

\section{RESULTS AND DISCUSSION}

Effects of urea treatment on the chemical composition of olive trees by products: The treatment of OTB with urea resulted in a linear increase in CP content by $6.87 \%\left(\mathrm{R}^{2}=0.976\right)$ as the level of urea treatment increased (Table 1). The positive improvement in the chemical composition of OTB after treatment with urea could be attributed to conversion of urea to ammonia in the bulk of the treated OTB. The resulted ammonia reacts with OTB particles and led for more OTB's fiber degradation especially lignin and increases its non-protein nitrogen (NPN) content. However, the rate of increase CP content of OTB with increasing level of urea was not constant. This may be due to the less nitrogen retention capacity for dry roughages when ammonized (Pires et. al., 2010). The Obtained results are in agreement with Resi et al. (1995), who reported significant improvement in $\mathrm{CP}$ content of hay treatment with ammonia. For fibrous content, urea has a potential effect in decreasing the fiber fractions content of OTB. Treatment of OTB with urea resulted in a gradual decrease in its content of NDF, ADF and ADL by 12.5, 14.1 and 7.9, respectively. This may be due to increasing in hemicellulose solubilization through breaking the ester linkage between lignin and hemicellulose, and partial break in hydrogen bounds of cellulose structure by ammonia (Garcíaet. al., 1999). Treatment with urea up to $4 \%$ appeared to be highly effective in lowering ADL content of OTB. However, using concentration above $4 \%$ seemed to be less effective. For fat content, the effect of urea treatment on EE content was limited compared with the other organic component in OTB.

Effects of urea treatment on the chemical composition of ewe's rations: Ewes of UOTB had ration with the lowest CP content, while CBH ewes had the lowest content for EE and NFE (Table, 2). Ewes of UOTB fed ration with the highest ADF content, while, ewes fed OTB4 and OTB6 rations had the lowest ADF content (221.4 and $217.6 \mathrm{~g} / \mathrm{kg} \mathrm{DM}$,) respectively.

Impact of urea treatment on ewe's body weight, feed intake and nutrients digestibility: Data in Table (3) shows the differences between ewe's groups in the daily feed intake, nutrients digestibility and body weight changes. Ewes of OTB4 and OTB6 had higher $(\mathrm{p}<0.05)$ feed intake, final body weight and body weight gain than those of $\mathrm{CBH}$ group. The lowest $(\mathrm{p}<0.05)$ feed intake, final body weight and body weight gain were 
observed for UOTB ewes, while the highest $(\mathrm{p}<0.05)$ feed intake, final body weight and body weight gain were recorded for OTB6 ewes. Its worth to mention that, there were no significant change in the body weight gain between ewes fed berseem hay and those fed untreated OTB. For nutrients digestibility, data of Table (3) shows that, there was no significant differences between ewes fed UOTB and CBH rations in DM, $\mathrm{CP}, \mathrm{CF}$ and NFE digestibility coefficients. However, ewes of $\mathrm{CBH}$ group showed slightly higher $(\mathrm{p}<0.05)$ OM, EE, NDF and ADF digestibility coefficients than those of UOTB. The ewes fed OTB treated with urea at level of $4 \%$ and $6 \%$ showed significant increase in all of nutrients digestibility coefficients than those fed both UOTB and $\mathrm{CBH}$ rations.

Table (1): Impact of urea treatment on the chemical composition of olive trees by-products

\begin{tabular}{|c|c|c|c|c|c|c|c|c|}
\hline Item & UOTB & OTB1 & OTB2 & OTB3 & OTB4 & OTB5 & OTB6 & $\mathrm{BH}$ \\
\hline \multicolumn{9}{|c|}{ Cheminal analysis (g/Kg DM) } \\
\hline $\mathrm{DM}$ & 897.2 & 906.8 & 912.2 & 915.0 & 930.0 & 932.1 & 938.9 & 912.4 \\
\hline $\mathrm{OM}$ & 830.0 & 833.0 & 840.0 & 844.0 & 851.8 & 855.0 & 858.0 & 880.1 \\
\hline Ash & 170.0 & 167.0 & 160.0 & 156.0 & 148.2 & 145.0 & 142.0 & 119.9 \\
\hline $\mathrm{CP}$ & 67.5 & 120.0 & 129.7 & 131.0 & 142.2 & 149.5 & 154.0 & 140.0 \\
\hline $\mathrm{CF}$ & 245.0 & 189.6 & 182.0 & 179.5 & 166.4 & 164.3 & 159.5 & 326.4 \\
\hline $\mathrm{EE}$ & 54.0 & 57.0 & 58.4 & 59.0 & 59.3 & 59.5 & 59.5 & 25.5 \\
\hline NFE & 463.5 & 466.4 & 469.9 & 474.5 & 483.9 & 481.7 & 485.0 & 388.2 \\
\hline \multicolumn{9}{|c|}{ Cell wall constituents (g/kg DM) } \\
\hline NDF & 525.4 & 505.8 & 482.9 & 464.1 & 449.4 & 446.5 & 443.0 & 447.0 \\
\hline $\mathrm{ADF}$ & 388.0 & 380.7 & 372.4 & 348.1 & 328.1 & 323.5 & 315.6 & 360.0 \\
\hline ADL & 121.0 & 113.0 & 104.5 & 98.9 & 78.5 & 78.0 & 77.8 & 71.3 \\
\hline Cellulose & 267.0 & 267.7 & 267.9 & 249.2 & 249.6 & 245.5 & 237.8 & 288.7 \\
\hline Hemicellulose & 137.4 & 125.1 & 110.5 & 116.0 & 121.3 & 123.0 & 127.4 & 87.0 \\
\hline
\end{tabular}

Table (2): Chemical composition of the experimental rations (g/kg of DM)

\begin{tabular}{lcccccc}
\hline Item & CFM & CBH & UOTB & OTB2 & OTB4 & OTB6 \\
\hline Chemical composition (\%): & & & & & \\
DM & 935.9 & 928.9 & 924.3 & 928.8 & 934.1 & 936.8 \\
OM & 920.6 & 908.5 & 893.4 & 896.4 & 900.0 & 901.8 \\
Ash & 79.4 & 91.6 & 106.6 & 103.6 & 100.0 & 98.2 \\
CP & 125.1 & 129.6 & 107.8 & 126.5 & 130.2 & 133.8 \\
CF & 113.5 & 177.4 & 153.0 & 134.1 & 129.4 & 127.3 \\
EE & 31.0 & 29.4 & 37.9 & 39.2 & 39.5 & 39.6 \\
NFE & 651.0 & 572.2 & 594.8 & 596.7 & 600.9 & 601.2 \\
Cell wall constituents $(\%)$ & & & & & \\
NDF & 306.5 & 348.7 & 372.2 & 359.4 & 349.4 & 347.5 \\
ADF & 175.6 & 230.9 & 239.3 & 234.6 & 221.4 & 217.6 \\
ADL & 68.5 & 69.3 & 84.3 & 79.3 & 71.5 & 71.3 \\
Cellulose & 107.1 & 161.6 & 155.1 & 155.3 & 149.9 & 146.3 \\
Hemicellulose & 130.9 & 117.7 & 132.9 & 124.8 & 128.0 & 129.9 \\
\hline
\end{tabular}

CFM, concentrated feed mixture; $C B H$, group fed $70 \%$ concentrate feed mixture $(C F M)+$ berseem hay ad lib; UOTB, group fed $70 \%$ concentrate feed mixture $(C F M)+$ untreated olive trees by products ad lib; OTB2, group fed 70\% concentrate feed mixture $(C F M)+$ olive trees by products treated with urea $(2 \% / \mathrm{kg} D M)$ ad lib; OTB4, group fed $70 \%$ concentrate feed mixture $(C F M)+$ olive trees by products treated with urea $(4 \% / \mathrm{kg} D M)$ ad lib; OTB6, group fed $70 \%$ concentrate feed mixture $(C F M)+$ olive trees by products treated with urea $(6 \% / \mathrm{kg} D M)$ ad lib. 
The observed significant increase in the daily feed intake in all groups fed urea treated OTB may be due to the significant decrease in OTB fibrous content and the improvement in fiber digestibility. These findings are supported by results of many researchers, whom reported that fiber content, specifically the NDF have a great influence on the intake and digestibility of roughages by small ruminants (Go'mez Cabrera et. al., 1982; Harper and McNeill, 2015). The live body weight improvement for ewes fed urea treated OTB at dose above $4 \%$ is may be due to positive effect of urea treatment on ration's nutritive values, digestibility and ewe's daily feed intake. These Results are in agreement with that reported by Molina-Alcaide and YáñezRuiz (2008), who found significant increase in OM digestibility due to urea treatment. In addition, Fegeros et al. (Fegeros et. al., 1995) found significant increase in the daily feed intake and apparent digestibility of CP, EE, NDF for fresh OTB treated with ammonia. In contrast (Delgado et al., 2000), observed a low apparent CP digestibility for olive leaf. This might be due to the differences in the method of preservation and the wood contents.

Table (3): Impact of urea treatment on ewe's body weight, feed intake and nutrients digestibility

\begin{tabular}{lcccccc}
\hline \multirow{2}{*}{ Item } & \multicolumn{5}{c}{ Experimental groups } \\
\cline { 2 - 7 } & CBH & UOTB & OTB2 & OTB4 & OTB6 & SE \\
\hline No. of animals & 4 & 4 & 4 & 4 & 4 & \\
\hline Initial body weight, Kg & 31.68 & 30.40 & 31.31 & 31.99 & 32.30 & 0.473 \\
Final body weight, Kg & $33.71^{\mathrm{b}}$ & $32.30^{\mathrm{c}}$ & $33.52^{\mathrm{b}}$ & $35.00^{\mathrm{a}}$ & $35.32^{\mathrm{a}}$ & 0.241 \\
Body weight change,Kg & $2.03^{\mathrm{b}}$ & $1.90^{\mathrm{b}}$ & $2.21^{\mathrm{b}}$ & $3.01^{\mathrm{a}}$ & $3.02^{\mathrm{a}}$ & 0.107 \\
Feed intake, g/h/d & $1393.91^{\mathrm{b}}$ & $1359.65^{\mathrm{c}}$ & $1412.5^{\mathrm{a}}$ & $1387.1^{\mathrm{b}}$ & $1426.03^{\mathrm{a}}$ & 6.43 \\
Digestibility, \% & & & & & & \\
DM & $64.17^{\mathrm{c}}$ & $63.04^{\mathrm{c}}$ & $67.84^{\mathrm{b}}$ & $71.41^{\mathrm{a}}$ & $70.81^{\mathrm{a}}$ & 0.424 \\
OM & $65.05^{\mathrm{c}}$ & $63.97^{\mathrm{d}}$ & $68.13^{\mathrm{b}}$ & $72.03^{\mathrm{a}}$ & $71.79^{\mathrm{a}}$ & 0.2 \\
EE & $72.50^{\mathrm{b}}$ & $71.34^{\mathrm{c}}$ & $73.04^{\mathrm{b}}$ & $74.80^{\mathrm{a}}$ & $74.77^{\mathrm{a}}$ & 0.315 \\
CP & $64.32^{\mathrm{c}}$ & $64.07^{\mathrm{c}}$ & $65.95^{\mathrm{b}}$ & $69.73^{\mathrm{a}}$ & $69.69^{\mathrm{a}}$ & 0.386 \\
CF & $53.28^{\mathrm{c}}$ & $52.38^{\mathrm{c}}$ & $56.76^{\mathrm{b}}$ & $61.34^{\mathrm{a}}$ & $61.24^{\mathrm{a}}$ & 0.493 \\
NFE & $68.13^{\mathrm{c}}$ & $67.45^{\mathrm{c}}$ & $69.045^{\mathrm{b}}$ & $70.89^{\mathrm{a}}$ & $70.56^{\mathrm{a}}$ & 0.278 \\
Fiber fractions, \% & & & & & & \\
NDF & $59.03^{\mathrm{c}}$ & $56.86^{\mathrm{d}}$ & $62.64^{\mathrm{b}}$ & $64.92^{\mathrm{a}}$ & $64.13^{\mathrm{a}}$ & 0.31 \\
ADF & $47.27^{\mathrm{c}}$ & $45.78^{\mathrm{d}}$ & $51.81^{\mathrm{b}}$ & $55.42^{\mathrm{a}}$ & $54.66^{\mathrm{a}}$ & 0.431 \\
\hline
\end{tabular}

${ }^{*}$ Means with different letter in the same row are significantly different at $(p<0.05)$.

CBH, group fed $70 \%$ concentrate feed mixture $(C F M)+$ berseem hay ad lib; UOTB, group fed $70 \%$ concentrate feed mixture $(C F M)+$ untreated olive trees by products ad lib; OTB2, group fed $70 \%$ concentrate feed mixture $(C F M)+$ olive trees by products treated with urea $(2 \% / \mathrm{kg} D M)$ ad lib; OTB4, group fed $70 \%$ concentrate feed mixture $(C F M)+$ olive trees by products treated with urea $(4 \% / \mathrm{kg} D M)$ ad lib; OTB6, group fed $70 \%$ concentrate feed mixture $(C F M)+$ olive trees by products treated with urea $(6 \% / \mathrm{kg} D M)$ ad lib.

Rumen parameters: Ewes fed on UOTB or urea treated OTB had lower $(\mathrm{p}<0.05)$ ruminal $\mathrm{pH}$ value compared to the CBH group (Table 4). Total volatile fatty acids (TVFA's) increased significantly in the rumen of groups fed urea treated OTB compared to those fed either UOTB or CBH. In contrast, group fed UOTB has the lowest ruminal concentration of TVFA's. The reduction of the ruminal $\mathrm{pH}$ after feeding is may be attributed to the rate of VFA's production in the rumen. During the fast fermentation process of nonstructural carbohydrates the rate of VFA production increase leading to a significant decrease in the rumen $\mathrm{pH}$. The noticeable increase $(\mathrm{p}<0.05)$ in the total VFA's concentration with decreasing ruminal $\mathrm{pH}$ in animals fed urea treated OTB is may be due to higher EE and NFE content of olive leaves than those of berseem hay. This is in agreement with that found by Reddy and Reddy (Reddy and Reddy, 1985); who stated that ruminal $\mathrm{pH}$ was inversely related to the concentration of TVFA's produced in the rumen $(\mathrm{p}<0.05)$. In addition, all groups fed urea treated OTB had significantly high ruminal total $\mathrm{N}$ concentration compared with other groups. However, UOTB group had a slightly lower $(\mathrm{p}<0.05)$ ruminal total $\mathrm{N}$ value compared to $\mathrm{CBH}$ group. Moreover, the lowest value $(\mathrm{p}<0.05)$ for ruminal true protein $(\mathrm{mg} / 100 \mathrm{ml})$ was recorded for the UOTB group followed by $\mathrm{CBH}$ then OTB2. However, OTB4 and OTB6 group had the 
Aboamer et al.

Table (4): Impact of experimental rations on ewe's ruminal parameters

\begin{tabular}{lcccccc}
\hline Item & CBH & UOTB & OTB2 & OTB4 & OTB6 & \pm SE \\
\hline PH & $6.77^{\mathrm{a}}$ & $6.35^{\mathrm{b}}$ & $6.25^{\mathrm{bc}}$ & $6.05^{\mathrm{d}}$ & $6.10^{\text {cd }}$ & 0.05 \\
TVFA's, mg/100 ml & $8.89^{\mathrm{c}}$ & $8.68^{\mathrm{d}}$ & $9.99^{\mathrm{b}}$ & $10.30^{\mathrm{a}}$ & $10.14^{\mathrm{ab}}$ & 0.07 \\
Total N, mg/100 ml & $111.12^{\mathrm{b}}$ & $107.02^{\mathrm{c}}$ & $122.14^{\mathrm{a}}$ & $124.45^{\mathrm{a}}$ & $123.82^{\mathrm{a}}$ & 0.87 \\
True protein N, mg/100 ml & $41.07^{\mathrm{c}}$ & $37.90^{\mathrm{d}}$ & $44.53^{\mathrm{b}}$ & $51.15^{\mathrm{a}}$ & $50.60^{\mathrm{a}}$ & 0.82 \\
NPN, mg/100 ml & $70.05^{\mathrm{bc}}$ & $69.12^{\mathrm{c}}$ & $77.61^{\mathrm{a}}$ & $73.30^{\mathrm{b}}$ & $73.21^{\mathrm{b}}$ & 1.11 \\
Ammonia N, mg/100 ml & $33.52^{\mathrm{d}}$ & $32.42^{\mathrm{e}}$ & $35.61^{\mathrm{c}}$ & $40.41^{\mathrm{b}}$ & $41.97^{\mathrm{a}}$ & 0.26 \\
\hline
\end{tabular}

${ }^{*}$ Means with different letter in the same row are significantly different at $(p<0.05)$.

CBH, group fed $70 \%$ concentrate feed mixture $(C F M)+$ berseem hay ad lib; UOTB, group fed $70 \%$ concentrate feed mixture $(C F M)+$ untreated olive trees by products ad lib; OTB2, group fed $70 \%$ concentrate feed mixture $(C F M)+$ olive trees by products treated with urea $(2 \% / \mathrm{kg} D M)$ ad lib; OTB4, group fed $70 \%$ concentrate feed mixture $(C F M)+$ olive trees by products treated with urea $(4 \% / \mathrm{kg} \mathrm{DM})$ ad lib; OTB6, group fed $70 \%$ concentrate feed mixture $(C F M)+$ olive trees by products treated with urea $(6 \% / \mathrm{kg} D M)$ ad lib.

Table (5): Impact of experimental rations on ruminal ciliate protozoa count $\left(\mathrm{x} 10^{4} \mathrm{cell} / \mathrm{ml}\right.$ rumen liquor)

\begin{tabular}{lllllll}
\hline \multirow{2}{*}{ Item } & \multicolumn{5}{c}{ Experimental group } \\
\cline { 2 - 6 } & CBH & UOTB & OTB2 & OTB4 & OTB6 & \pm SE \\
\hline Entodinum spp. & $5.988^{\mathrm{c}}$ & $5.782^{\mathrm{d}}$ & $6.182^{\mathrm{b}}$ & $6.693^{\mathrm{a}}$ & $6.325^{\mathrm{b}}$ & 0.049 \\
Epidinium spp. & $0.236^{\mathrm{b}}$ & $0.234^{\mathrm{b}}$ & $0.247^{\mathrm{a}}$ & $0.251^{\mathrm{a}}$ & $0.245^{\mathrm{a}}$ & 0.002 \\
Diplodinum spp. & $0.205^{\mathrm{bc}}$ & $0.202^{\mathrm{c}}$ & $0.208^{\mathrm{b}}$ & $0.215^{\mathrm{a}}$ & $0.213^{\mathrm{a}}$ & 0.001 \\
Ophryoscoloxspp & $0.246^{\mathrm{bc}}$ & $0.243^{\mathrm{c}}$ & $0.249^{\mathrm{ab}}$ & $0.250^{\mathrm{a}}$ & $0.245^{\mathrm{c}}$ & 0.001 \\
Polyolastron spp. & $0.403^{\mathrm{d}}$ & $0.404^{\mathrm{cd}}$ & $0.417^{\mathrm{b}}$ & $0.440^{\mathrm{a}}$ & $0.412^{\mathrm{bc}}$ & 0.002 \\
Isotrchia spp. & $0.281^{\mathrm{ab}}$ & $0.280^{\mathrm{ab}}$ & $0.270^{\mathrm{b}}$ & $0.289^{\mathrm{a}}$ & $0.284^{\mathrm{ab}}$ & 0.004 \\
Dasytrachia spp. & $0.476^{\mathrm{c}}$ & $0.490^{\mathrm{b}}$ & $0.498^{\mathrm{b}}$ & $0.526^{\mathrm{a}}$ & $0.501^{\mathrm{b}}$ & 0.004 \\
Total protozoa count & $7.838^{\mathrm{e}}$ & $7.637^{\mathrm{d}}$ & $8.073^{\mathrm{c}}$ & $8.667^{\mathrm{a}}$ & $8.227^{\mathrm{b}}$ & 0.049 \\
\hline
\end{tabular}

${ }^{*}$ Means with different letter in the same row are significantly different at $(p<0.05)$.

$C B H$, group fed $70 \%$ concentrate feed mixture $(C F M)+$ berseem hay ad lib; UOTB, group fed $70 \%$ concentrate feed mixture $(C F M)+$ untreated olive trees by products ad lib; OTB2, group fed $70 \%$ concentrate feed mixture $(C F M)+$ olive trees by products treated with urea $(2 \% / \mathrm{kg} D M)$ ad lib; OTB4, group fed $70 \%$ concentrate feed mixture $(C F M)+$ olive trees by products treated with urea $(4 \% / \mathrm{kg} D M)$ ad lib; OTB6, group fed $70 \%$ concentrate feed mixture $(C F M)+$ olive trees by products treated with urea $(6 \% / \mathrm{kg} D M)$ ad lib.

highest level of ruminal true protein, with no significant differences between them. There were no significant differences in ruminal NPN concentration between the CBH and UOTB groups. However, the OTB2 group had the highest value of ruminal NPN concentration followed by OTB4 and OTB6. Ammonia N levels were gradually increased $(\mathrm{p}<0.05)$ by increasing level of treatment with urea. The observed increase $(\mathrm{p}<0.05)$ in ruminal NPN and ammonia N concentration in ewe's groups fed the urea treated OTB might be a direct result to urea treatment. The effects of experimental rations on ruminal ciliate protozoa $\left(\mathrm{x} 10^{4} \mathrm{cell} / \mathrm{ml}\right.$ rumen liquor) are presented in Table (5). In general, Entodinum spp. was the prevailing protozoa in the rumen with the highest concentration. Ewes of UOTB group had the lowest number of ruminal Entodinum spp. In contrast, ewes fed urea-treated OTB had higher concentration of Entodinum spp. than those fed UOTB and CBH rations. The highest $(\mathrm{p}<0.05)$ concentration of Entodinum spp. in the rumen was observed for OTB4 group. There were no significant differences in Epidinium spp. concentration between UOTB and CBH group. However, ewes fed treated OTB showed higher count for Epidinium spp. without significant effect for the level of urea. The experimental ewe's groups were less differed in rumen concentration of Diplodinum spp., Ophryoscolox spp, and Isotrchia spp. However, the differences were significant. OTB4 group had the highest ruminal concentration of Polyolastron spp. In addition, the CBH group had the lowest concentration of Dasytrachia spp., while the highest concentration was for OTB4 group (0.476 vs 0.526 , respectively). For total protozoa count, UOTB group had the lowest number followed by CBH group, while, 
OTB4 had the highest ruminal total protozoal count. In general, ruminal protozoal count of ewes fed untreated OTB seemed to be low; however, urea treatment significantly increased the total protozoal count. This may be due to the lack of soluble carbohydrate in untreated OTB. Results are in agreement with that found by Yáñez Ruiz et. al. (1995).

Blood parameters: Blood parameters often reflect the physiological and biochemical status of the animals. The lowest blood serum total protein level was observed in the group fed UOTB, however all groups fed urea treated OTB showed significant higher levels of blood total proteins (Table 6). The same trend was observed for serum albumin level. However, UOTB and OTB4 group had almost the same blood globulin concentrations. The obtained data for serum total protein concentration was within the normal range (5.9 7.8, g/dl), reported by (Doyle andGordon, 2008). However, urea treatment increased the serum albumin level $(\mathrm{p}<0.05)$ compared with UOTB and CBH groups. Blood albumin adheres chemically to various substances such as amino acids in the blood, playing a role in their transport (Rivera et. al., 2005). Oh et. al. (2008) concluded that, increasing albumin level could be explained by more absorption of true protein in the small intestine. Increasing the serum urea level could be attributed to excessive tissues protein catabolism associated with protein deficiency (Njidda et. al., 2013). Therefore, urea treatment could be useful in support diets with low protein content. Serum urea concentration was markedly lower $(p<0.05)$ in all groups fed urea treated OTB compared to UOTB or CBH group. However, increasing level of urea treatment had no significant effect on blood urea concentration. There were a slight differences $(\mathrm{p}<0.05)$ among all groups in concentrations of aminotransferases (AST and ALT) and the highest observed value was for the UOTB group. Aminotransferases in blood act as a catalyst in connecting the metabolism of amino-acids and carbohydrates. Their activity in the blood can be a consequence of their increased activity in cells (primarily liver), but also a reflection of cell structure damage (Stojevi'c et. al., 2005). Results show no adverse effect on blood serum aminotransferases levels due to urea treatment.

Table (6): Impact of experimental rations on ewe's blood composition

\begin{tabular}{|c|c|c|c|c|c|c|}
\hline \multirow{2}{*}{ Item } & \multicolumn{5}{|c|}{ Experimental group } & \multirow{2}{*}{$\pm \mathrm{SE}$} \\
\hline & $\mathrm{CBH}$ & UOTB & OTB2 & OTB4 & OTB6 & \\
\hline Total proteins, $\mathrm{g} / \mathrm{dl}$ & $6.77^{\mathrm{c}}$ & $6.36^{\mathrm{d}}$ & $7.14^{b}$ & $7.73^{\mathrm{a}}$ & $7.19^{b}$ & 0.107 \\
\hline Albumin, g/dl & $3.58^{\mathrm{c}}$ & $3.37^{\mathrm{d}}$ & $3.89^{\mathrm{b}}$ & $4.80^{\mathrm{a}}$ & $4.01^{\mathrm{b}}$ & 0.072 \\
\hline Globulin, g/dl & $3.19^{\mathrm{ab}}$ & $2.99^{\mathrm{bc}}$ & $3.25^{\mathrm{a}}$ & $2.93^{\mathrm{c}}$ & $3.18^{\mathrm{ab}}$ & 0.096 \\
\hline $\mathrm{A} / \mathrm{G}$ ratio & $1.12^{\mathrm{c}}$ & $1.13^{\mathrm{c}}$ & $1.20^{\mathrm{bc}}$ & $1.64^{\mathrm{a}}$ & $1.26^{\mathrm{b}}$ & 0.038 \\
\hline Urea, mg/dl & $38.42^{\mathrm{a}}$ & $37.10^{\mathrm{a}}$ & $28.58^{\mathrm{b}}$ & $27.93^{\mathrm{b}}$ & $27.21^{\mathrm{b}}$ & 1.072 \\
\hline $\mathrm{AST}, \mathrm{U} / \mathrm{L}$ & $24.83^{\mathrm{ab}}$ & $25.66^{\mathrm{a}}$ & $23.39^{\mathrm{b}}$ & $23.18^{\mathrm{b}}$ & $23.45^{\mathrm{b}}$ & 0.635 \\
\hline ALT, U/L & $5.69^{\mathrm{ab}}$ & $6.09^{\mathrm{a}}$ & $5.79^{\mathrm{a}}$ & $4.77^{\mathrm{b}}$ & $5.76^{\mathrm{a}}$ & 0.312 \\
\hline
\end{tabular}

CBH, group fed $70 \%$ concentrate feed mixture $(C F M)+$ berseem hay ad lib; UOTB, group fed $70 \%$ concentrate feed mixture $(C F M)+$ untreated olive trees by products ad lib; OTB2, group fed $70 \%$ concentrate feed mixture $(C F M)+$ olive trees by products treated with urea $(2 \% / \mathrm{kg}$ DM) ad lib; OTB4, group fed $70 \%$ concentrate feed mixture (CFM) + olive trees by products treated with urea $(4 \% / \mathrm{kg} \mathrm{DM)} \mathrm{ad} \mathrm{lib;} \mathrm{OTB6,} \mathrm{group} \mathrm{fed} 70 \%$ concentrate feed mixture (CFM) + olive trees by products treated with urea $(6 \% / \mathrm{kg} \mathrm{DM)} \mathrm{ad} \mathrm{lib.}$

Milk yield and its composition: There were no significant differences in the daily milk yield, $4 \%$ fat corrected milk (FCM), and milk constituents between the groups fed UOTB and CBH. However, all groups fed urea treated OTB produced more $(\mathrm{p}<0.05)$ daily milk and 4\% FCM (Table 7). The highest daily milk yield $(\mathrm{g} / \mathrm{h} / \mathrm{d})$ and 4\% FCM (g/h/d) were observed in OTB4 group, being 1070.95 and 1026, respectively. In addition, the OTB4 group had the highest $(\mathrm{p}<0.05)$ milk total solids, solids not fat $(\mathrm{SNF})$, fat, total protein, lactose, and ash content (\%).The improvement in milk production and its composition might be due to the improvement in chemical composition and nutrient digestibility of OTB after treatment with urea. The obtained results of daily milk yield and composition are in parallel with those obtained in the digestibility trial. The current results are in line with those of (Verma and Jackson, 1984) they reported that dairy animals of low milk production showed a significant response to urea treatment. Also, Mapato et. al. (2010) noted that cows fed on urea treated rice straw had higher production of 3.5\% FCM than those fed on untreated rice straw. 
Aboamer et al.

Table (7): Impact of experimental rations on ewe's milk yield and its composition

\begin{tabular}{lcccccc}
\hline \multirow{2}{*}{ Item } & \multicolumn{5}{c}{ Experimental group } & \multirow{2}{*}{ \pm SE } \\
\cline { 2 - 5 } & CBH & UOTB & OTB2 & OTB4 & OTB6 & \\
\hline Milk yield g/h/d & $935.47^{\mathrm{d}}$ & $931.66^{\mathrm{d}}$ & $991.19^{\mathrm{c}}$ & $1070.95^{\mathrm{a}}$ & $1043.80^{\mathrm{b}}$ & 5.875 \\
$4 \%$ FCM g/h/d & $869.21^{\mathrm{d}}$ & $863.77^{\mathrm{d}}$ & $930.71^{\mathrm{c}}$ & $1026.20^{\mathrm{a}}$ & $987.16^{\mathrm{b}}$ & 5.508 \\
Total solids & $12.409^{\mathrm{d}}$ & $12.38^{\mathrm{d}}$ & $12.51^{\mathrm{c}}$ & $13.00^{\mathrm{a}}$ & $12.66^{\mathrm{b}}$ & 0.015 \\
Fat & $3.53^{\mathrm{d}}$ & $3.51^{\mathrm{d}}$ & $3.59^{\mathrm{c}}$ & $3.72^{\mathrm{a}}$ & $3.64^{\mathrm{b}}$ & 0.007 \\
Solids not fat & $8.87^{\mathrm{c}}$ & $8.86^{\mathrm{c}}$ & $8.91^{\mathrm{c}}$ & $9.28^{\mathrm{a}}$ & $9.01^{\mathrm{b}}$ & 0.016 \\
Total protein & $3.77^{\mathrm{d}}$ & $3.76^{\mathrm{d}}$ & $3.88^{\mathrm{c}}$ & $4.00^{\mathrm{a}}$ & $3.92^{\mathrm{b}}$ & 0.004 \\
Lactose & $4.19^{\mathrm{d}}$ & $4.17^{\mathrm{d}}$ & $4.43^{\mathrm{c}}$ & $4.57^{\mathrm{a}}$ & $4.49^{\mathrm{b}}$ & 0.013 \\
Ash & $0.979^{\mathrm{c}}$ & $0.977^{\mathrm{c}}$ & $1.013^{\mathrm{b}}$ & $1.021^{\mathrm{a}}$ & $1.016^{\mathrm{ab}}$ & 0.002 \\
\hline
\end{tabular}

${ }^{*}$ Means with different letter in the same row are significantly different at $(p<0.05)$.

$C B H$, group fed $70 \%$ concentrate feed mixture $(C F M)+$ berseem hay ad lib; UOTB, group fed $70 \%$ concentrate feed mixture $(C F M)+$ untreated olive trees by products ad lib; OTB2, group fed $70 \%$ concentrate feed mixture $(C F M)+$ olive trees by products treated with urea $(2 \% / \mathrm{kg} D M)$ ad lib; OTB4, group fed $70 \%$ concentrate feed mixture $(C F M)+$ olive trees by products treated with urea $(4 \% / \mathrm{kg} D M)$ ad lib; OTB6, group fed $70 \%$ concentrate feed mixture $(C F M)+$ olive trees by products treated with urea $(6 \% / \mathrm{kg} D M)$ ad lib.

\section{CONCLUSION}

Treatment of olive trees by-products with urea not only increase their content of crud protein but also increase their fiber degradability by increasing hemicellulose solubilization through breaking the ester linkage between lignin and hemicellulose, and causing partial break in hydrogen bonds of cellulose structure. This treatment could be beneficial for the animal breeders as it consider as one of the cheapest and effective process to improve the nutritive value of the agriculture by-products. In the current study, feeding of lactating ewes on OTB with $4 \%$ urea solution improved their milk production and milk composition with no deleterious effects on ewe's health.

\section{REFERENCES}

Njidda, A. A., Hassan, I. T. and E. A. Olatunji (2013). Haematological and biochemical parameters of goats of semi arid environment fed on natural grazing rangeland of northern Nigeria. IOSR Journal of Agriculture and Veterinary Science, 3(2), 1-8. doi:10.9790/2380-0320108.

Azzaz, H. H., Ebeid, H. M., Morsy, T. A., and S. M. Kholif (2015). Impact of feeding yeast culture or yeast culture and propionibacteria 169 on the productive performance of lactating Buffaloes. International Journal of Dairy Science, 10(3), 107-116. doi:10.3923/ijds.2015.107.116.

Azzaz, H.H, Hend A. Aziz, Hoda Alzahar and H.A. Murad (2018). Yeast and Trichoderma viride don't synergistically work to improve olive trees by products digestibility and lactating Barki ewe's productivity. Journal of Biological Sciences, 18 (6): 270-279. doi:10.3923/jbs.2018.270.279.

Delgado-Pertíñez, M., Chesson, A., Provan, G. J., Garrido, A., and A. Gómez-Cabrera (1998). Effect of different drying systems for the conservation of olive leaves on their nutritive value for ruminants. Annales de Zootechnie, 47(2), 141-150. doi:10.1051/animres:19980206

Delgado-Pertíñez, M., Gómez-Cabrera, A., and A. Garrido (2000). Predicting the nutritive value of the olive leaf (Olea europaea): digestibility and chemical composition and in vitro studies. Animal Feed Science and Technology, 87(3-4), 187-201. doi:10.1016/s0377-8401(00)00195-4.

Dijkstra, J. (1994). Production and absorption of volatile fatty acids in the rumen. Livestock Production Science, 39(1), 61-69. doi:10.1016/0301-6226(94)90154-6. 
Doyle, K., and H. Gordon (2008). Merck Veterinary Manual. Australian Veterinary Journal, 70(7), 278-278. doi:10.1111/j.1751-0813.1993.tb08058.x.

Duncan, D. B. (1955). Multiple Range and Multiple F Tests. Biometrics, 11(1), 1. doi:10.2307/3001478.

Fegeros, K., Zervas, G., Apsokardos, F., Vastardis, J., and E. Apostolaki (1995). Nutritive evaluation of ammonia treated olive tree leaves for lactating sheep. Small Ruminant Research, 17(1), 9-15. doi:10.1016/0921-4488(95)00657-7.

Ferret, A., Plaixats, J., Caja, G., Gasa, J., and P. Prió (1999). Using markers to estimate apparent dry matter digestibility, faecal output and dry matter intake in dairy ewes fed Italian ryegrass hay or alfalfa hay. Small Ruminant Research, 33(2), 145-152. doi:10.1016/s0921-4488(99)00015-2.

García, J., Carabaño, R., and J. C. de Blas (1999). Effect of fiber source on cell wall digestibility and rate of passage in rabbits. Journal of Animal Science, 77(4), 898. doi:10.2527/1999.774898x.

Go'mez Cabrera A., Parellada, J., Garrido, A. and F. Ocaña (1982). Olive leaves utilisation in animal feeding. ii, Nutritive value. Avances en Alimentación y Mejora Anim 23: 75-77.

Harper, K., and D. McNeill (2015). The Role iNDF in the Regulation of Feed Intake and the Importance of Its Assessment in Subtropical Ruminant Systems (the Role of iNDF in the Regulation of Forage Intake). Agriculture, 5(3), 778-790. doi:10.3390/agriculture5030778.

International olive council, (2006). http://www.internationaloliveoil.org.

Mapato, C., Wanapat, M., and A. Cherdthong (2010). Effects of urea treatment of straw and dietary level of vegetable oil on lactating dairy cows. Tropical Animal Health and Production, 42(8), 1635-1642. doi:10.1007/s11250-010-9613-3.

Molina Alcaide, E., and A. Nefzaoui (1996). Recycling of olive oil by-products: Possibilities of utilization in animal nutrition. International Biodeterioration \& Biodegradation, 38(3-4), 227-235. doi:10.1016/s09648305(96)00055-8.

Molina Alcaide, E., Ruiz, D. R. Y., Moumen, A., and A. I. M. García (2003). Ruminal degradability and in vitro intestinal digestibility of sunflower meal and in vitro digestibility of olive by-products supplemented with urea or sunflower meal. Animal Feed Science and Technology, 110(1-4), 3-15. doi:10.1016/j.anifeedsci.2003.08.002.

Molina-Alcaide, E., and D. R. Yáñez-Ruiz (2008). Potential use of olive by-products in ruminant feeding: A review. Animal Feed Science and Technology, 147(1-3), 247-264. doi:10.1016/j.anifeedsci.2007.09.021.

Naga, M. A., Abou Akkada, A. R., and K. El-Shazly (1969). Establishment of Rumen Ciliate Protozoa in Cow and Water Buffalo (Bos bubalus L.) Calves under Late and Early Weaning Systems. Journal of Dairy Science, 52(1), 110-112. doi:10.3168/jds.s0022-0302 (69)86510-0.

Official methods of analysis of AOAC International, 16th ed., (1997). Choice Reviews Online, 35(02), 350912-35-0912. doi:10.5860/choice.35-0912.

Oh, Y.-K., Kim, J.-H., Kim, K.-H., Choi, C.-W., Kang, S.-W., Nam, I.-S., and K.-K., Park (2008). Effects of level and degradability of dietary protein on ruminal fermentation and concentrations of soluble nonammonia nitrogen in ruminal and omasal digesta of Hanwoo Steers. Asian-Australasian Journal of Animal Sciences, 21(3), 392-403. doi:10.5713/ajas.2008.70342.

Pires, A. J. V., Carvalho, G. G. P. de, and L. S. O. Ribeiro (2010). Chemical treatment of roughage. Revista Brasileira de Zootecnia, 39(suppl spe), 192-203. doi:10.1590/s1516-35982010001300022.

Reddy, K. J. and M. Reddy (1985). Effect of feeding complete feeds on various nitrogen fractions and total VFA concentrations in the rumen fluid of sheep, Indian journal of animal sciences 9: 819.

Reis, L. A. Rodrigues, P. Pedroso (1995). Evaluation of ammonia sources for treatment of roughages, Revista da Sociedade Brasileira de Zootecnia. 24(4): 486-493.

Rivera, J. D., Bachman, S. E., Hubbert, M. E., Branine, M. E., Horst, R. L., Williams, S. N., and M. L. Galyean (2005). Short communication: Serum and tissue concentrations of vitamin D metabolites in beef heifers after buccal dosing of 25-Hydroxyvitamin D3. Journal of Dairy Science, 88(4), 1364-1369. doi:10.3168/jds.s0022-0302 (05)72803-4. 
Romaniello, R., Tamborrino, A., and A. Leone (2018). Mobile Elevated Work Platforms versus Ladders in Olive Tree Pruning: Evaluation of Physical Activity and Pruning Performance. Journal of Agricultural Safety and Health, 24(3), 141-153. doi:10.13031/jash.12720.

SAS (1998). SAS user guide: statistics version 9 edition, SAS institute inc., Cary, NC.

Stojevi'c Z., Pir`sljin, J., Milinkovi'c-Tur, S., Zdelar-Tuk, M., and B. B. Ljubi'c (2005). Activities of AST, ALT and GGT in clinically healthy dairy cows during lactation and in the dry period, Veterinarski arhiv 75(1): 67-73.

Van Soest, P. J., Robertson, J. B., and B. A. Lewis (1991). Methods for Dietary Fiber, Neutral Detergent Fiber, and Nonstarch Polysaccharides in Relation to Animal Nutrition. Journal of Dairy Science, 74(10), 3583-3597. doi:10.3168/jds.s0022-0302 (91)78551-2.

Verma M. L., and M. G. Jackson (1984). Straw etc. in practical rations for cattle and buffaloes. In: Straw and other fibrous by-products as feed, Sundstøl, F., and Owen, E. (Eds.). Elsevier, pp414-430.

Yáñez Ruiz, D. R., Martín García, A. I., Moumen, A., and E. Molina Alcaide (2004). Ruminal fermentation and degradation patterns, protozoa population and urinary purine derivatives excretion in goats and wethers fed diets based on olive leaves1. Journal of Animal Science, 82(10), 3006-3014. doi:10.2527/2004.82103006x.

Yáñez Ruiz, D., Moumen, A., and E. Molina Alcaide (2004). Comparative studies on microbial protein synthesis in the rumen of goats and sheep. Journal of Animal and Feed Sciences, 13(Suppl. 1), 251-254. doi: $10.22358 /$ jafs/73852/2004. 


\title{
تأثير مخلفات أشجار الزيتون المعامله باليوريا على هضم العناصر الغذائية وانتاج اللبن من نعاج البرقى
}

\author{
أحمد عبد القادر ابراهيم ابو عامر ب, هند أحمد على عزيز2, حسام الدين حسين عزاز عبد الفتاح', هدى الزهار حسن, حسين \\ عزاز عبد القتاح مراد الهي \\ 1 قسم علوم الالبان- المركز القومى للبحوث- 33 شارع البحوث ـ الدقى - جبزة - مصر \\ 2- قسم تغذية الحيوان - مركز بحوث الصحراء ـ القاهرة - مصر
}

هدف البحث هو دراسة اثر معاملة مخلفات اثجار الزيتون بمستويات متز ايدة من اليوريا واستخدامها كبديل لدريس البرسيم في علائق النعاج البرقي الحلابة ودر اسة أثر ذللك على معاملات الهضم و التتاج اللبن.

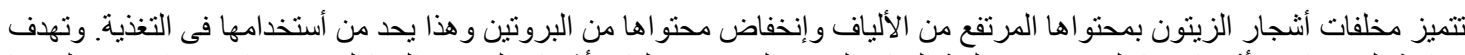

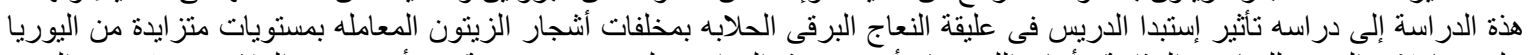

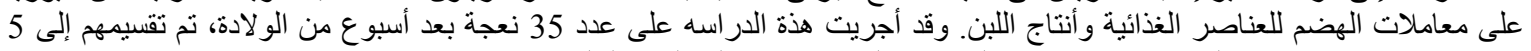

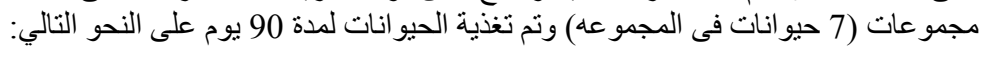

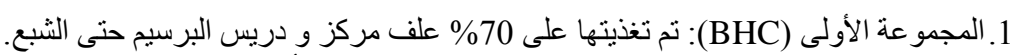

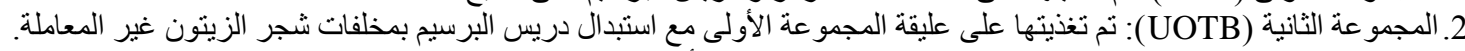

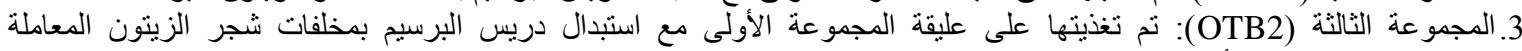

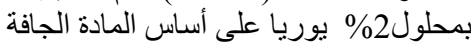

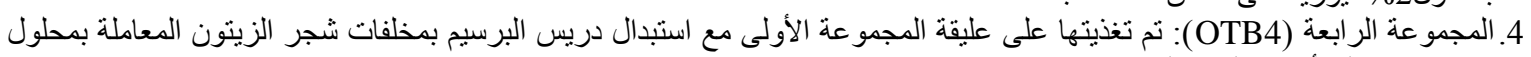
4 \% بوريا على أساس المادة الجافة :

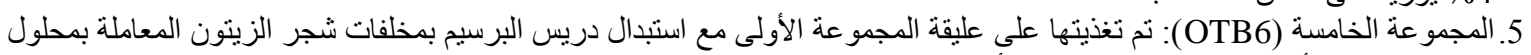

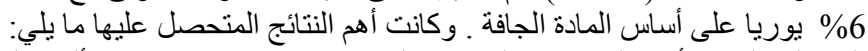

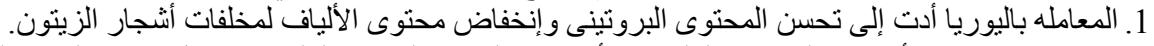

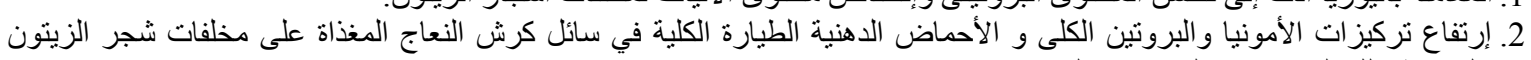

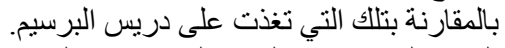

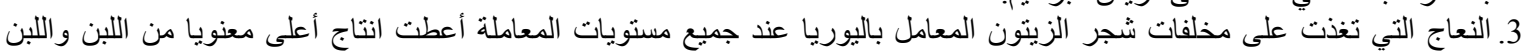
المعدل نسبة الدهن وكذلك نسب مكونات اللبن.

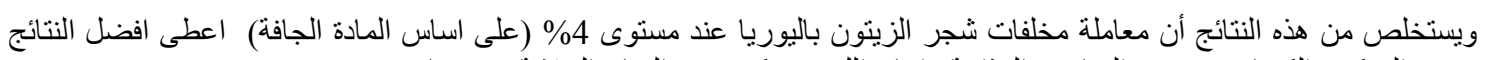
فى تحسين التركيب الكيماوى و هضم العناصر الغذائية و انتاج اللبن وتركيبه بالئه من النعاج الحلابة مزر عيا. 